\title{
ON A COLLECTION OF PLEUROSTICT SCARABAEIDAE (COLEOPTERA) FROM THE GREAT HIMALAYAN NATIONAL PARK, HIMACHAL PRADESH, INDIA
}

\author{
Kailash Chandra ${ }^{1}$ and V.P. Uniyal ${ }^{2}$ \\ ${ }^{1}$ Zoological Survey of India, Central Regional Station, 168/169, Scheme No. 5, Vijay Nagar, Jabalpur, Madhya Pradesh 482002, India \\ ${ }^{2}$ Wildlife Institute of India, Post Box \# 18, Chandrabani, Dehradun, Uttaranchal 248001, India \\ Email: ${ }^{1}$ kailash611@ rediffmail.com; ${ }^{2}$ uniyalvp@ wii.gov.in
}

\begin{abstract}
The paper incorporates faunistic record of a small collection of Scarabaeidae comprising three species of Melolonthinae, two species of Rutelinae, three species of Dynastinae, and one species of Cetoniinae from Great Himalyan National Park under Forestry Research Education and Extention (F.R.E.E.) Project.
\end{abstract}

KEYworDS

Cetoniinae, Dynastinae, Great Himalayan NP, Melolonthinae, Rutelinae, Scarabaeidae

The family Scarabaeidae can be divided into two groups on the basis of position of the abdominal spiracles. The scavenger beetles feeding upon dung, carrion, and other dead vegetable matter are kept in Laparosticti, while leaf-chafers feeding mostly on leaves, roots and other parts of plants are kept in Pleurosticti. Chandra (1988) studied the pleurostict Scarabaeidae (Coleoptera) of northwestern India and 108 species pertaining to four subfamilies were reported. An account of scarabaeid beetles of Himachal Pradesh was also published by Chandra (2004) and a total 167 species under eight subfamilies were reported, which included only 30 species of plerostict Scarabaeidae from Kulu district. The information on other insects of Great Himalayan National Park were published by Uniyal (1999), Uniyal \& Kumar (1997), Uniyal \& Mathur (1998, 2000), but the information on these beetles particularly from the Great Himalayan National Park (GHNP) is completely lacking. Hence, while undertaking the survey of GHNP during FREEP-GHNP research programme for the comprehensive study of faunal diversity of the NP, nine species of pleurostict Scarabaeidae were identified. The nomenclature is mainly following Arrow (1910, 1917, 1932).

\section{Study Area}

Great Himalayan National Park is situated between $31^{\circ} 38^{\prime} 16^{\prime \prime}-31^{\circ} 45^{\prime} 41^{\prime \prime} \mathrm{N} \& 77^{\circ} 20^{\prime}-77^{\circ} 52^{\prime} 11^{\prime \prime E}$ in Kulu district of Himachal Pradesh, covering a total area of $1,171 \mathrm{~km}^{2}$. The park consists of the catchments of Tirthan, Sainj, Jiwa and Parvati rivers flowing into the Beas river. The variation in altitude ranges from 1,300 to $6,110 \mathrm{~m}$ above mean sea level. These beetles were collected during the months of April and May, 1996 from light sources of different places of GHNP (Figure 1).

\section{ObSERVATIONS}

Subfamily: Melolonthinae

Hilyotrogus holosericeus (Redtenbacher)

Ancylonycha holosericeus Redtenbacher, in Hugel, Reise Kaschmir IV, 2, 1844, p.524

Schizonycha holosericeus, Gemminger, et. Harold, Cat. Col. IV, 1869, p.1159.

Ancylonycha brevicollis, Blanchard,Cat. Coll. Ent. I, 1850, p.132.
Hilyotrogus holosericeus, Brenske, Berl. Ent. Zeitschr. XXXVII, 1892, p.171.

Material examined: 26.v.1996,1 ex. (female), Great Himalayan National Park (GHNP), Sainj, alt. 2340m, coll. V.P. Uniyal.

Diagnosis: Length 14.5-15.0mm, breadth 7.5-8.0mm; body elongate oval and convex; testaceous-yellow, sternum covered with soft dense hairs. Clypeus round, slightly sinuate in middle, front margin reflexed, strongly punctate with deep punctures; frons and vertex punctate with few punctures, frontal suture distinct. Pronotum transverse, thinly punctate on disc and rather densely on sides, anterior and posterior angles obtuse, lateral margins nearly rounded. Scutellum sparsely punctate. Elytra not covering propygidium, rather densely, finely and deeply punctate. Fore tibiae tridentate; middle and hind tibiae with a longitudinal carinae; tarsi longer than tibia; claws cleft. Pygidium triangular and coarsely punctate. In male, antennal club 5-segmented with an additional short sixth one.

Distribution: India (Himachal Pradesh, Kashmir).

\section{Melolontha furcicauda Ancey}

Melolontha furcicauda Ancey, Naturaliste III, 1881, p.412.

Material examined: 17.v.96, 2 ex., GHNP, Dhagra, alt. 2260m., coll. V.P. Uniyal.

Diagnosis: Length $32.0 \mathrm{~mm}$, breadth $15.0 \mathrm{~mm}$; body elongate, convex; brown-red, covered all over with a pale scales. Head closely setose and densely and unevenly punctate; clypeus rectangular, with margins strongly reflexed and feebly excised in front. Antennae 10-segmented, club 7-segmented and very long in male. Pronotum finely and densely granulate on sides and closely punctate in middle, with scales minute on sides and large in middle; lateral margins gently rounded; anterior angles very obtuse, posterior angles prominent and right angles; base moderately strongly lobed in middle, Scutellum very finely and closely punctate. Elytra with flat and densely scaly intervals; intervals raised, narrow, with denuded costae. Metasternum densely covered with long and fine hairs. Sides of abdomen large with white patches of dense fine scales. Pygidium long and projected behind into a bifurcated tail.

Distribution: India (Himachal Pradesh, Kashmir) and China.

\section{Melolontha indica Hope}

Melolontha indica_Hope, Gray's Zool. Misc. I, 1831, p.23.

Material examined: 17.v.96, 1 ex., GHNP, Dhagra, alt. 2260m, coll. V.P. Uniyal.

Diagnosis: Length $28.0 \mathrm{~mm}$, breadth $13.0 \mathrm{~mm}$; body elongate; dark brown, clothed very densely and evenly with pale scales. Head closely setose, strongly and closely punctate; clypeus rectangular, margin strongly reflexed and very weakly sinuate in middle. Antennae 10segmented, club 7-segmented, very long and flat. Pronotum very finely and closely punctate; a little roughly granulated at sides; lateral margins strongly rounded; anterior angles blunt but very obtuse, posterior angles sharp and right angles; base lobed in middle. Scutellum short and closely setose. Elytra densely and evenly covered with scales, costae feebly raised. Metasternum thickly covered with long silky hair. Mesosternum produced horizontally into a long tapering process. Fore tibiae sharply tridentate; claws feebly toothed at base. Pygidium elongate and projected behind into a slightly bifid process.

Distribution: India (Himachal Pradesh).

Manuscript 1458; (C) ZOO; Date of publication 21 August 2007; Received 05 November 2005; Revised received 15 March 2007; Finally accepted 27 July 2007 


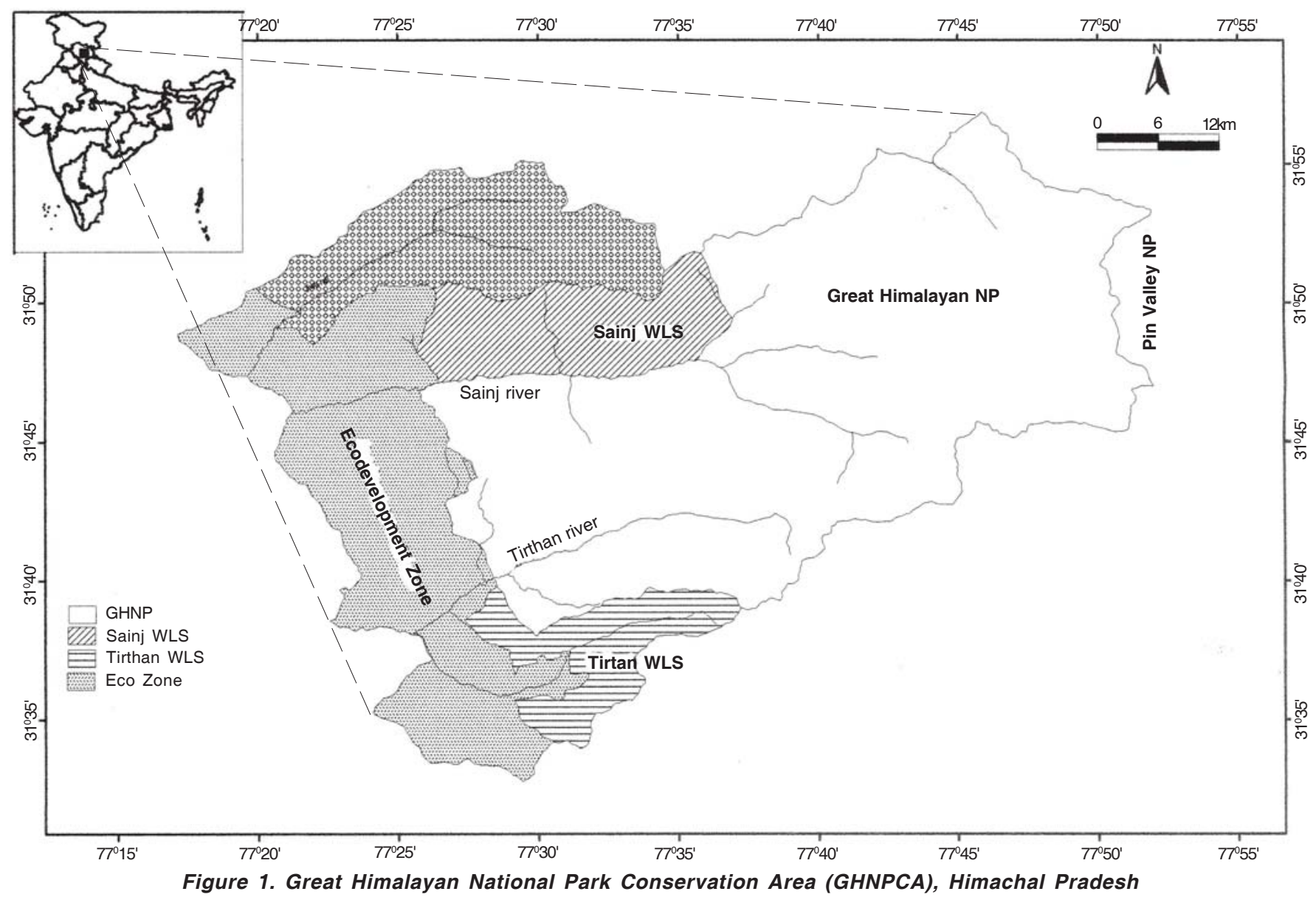

\section{Subfamily: Rutelinae}

Anomala dimidiata (Hope)

Euchlora dimidiata Hope, in Gray, Zool. Misc., 1831, p.23.

Anomala dimidiata, Arrow, Fauna Brit. Ind.,Coleopt. Lamell., II, 1917, p.232, t.2, f.16.

Material examined: 19.v.1996, 1 ex., GHNP, Niveli, alt. 1630m, coll. V.P. Uniyal.

Diagnosis: Length $20.0-24.0 \mathrm{~mm}$, breadth $11.5-13.5 \mathrm{~mm}$; form broadly oval. Clypeus densely and frons less densely punctate. Pronotum finely and moderately closely punctate, and coarsely and confluently at sides; scutellum finely punctate; elytra finely and fairly closely punctate, with slight traces of longitudinal lines. Pygidium moderately finely and transversely rugose. In male, teeth of fore femur short and sharp.

Distribution: India (Haryana, Himachal Pradesh, Punjab, Uttar Pradesh, West Bengal, Sikkim, Assam, Meghalaya, and Manipur) and Nepal.

\section{Anomala rufiventris Redtenbacher}

Anomala rufiventris Redtenbacher, in Hugel, Kaschmir, Kafer, IV, 2, 1842 , p.526.

Anomala rufiventris, Burmeister, Handb. Ent. IV, 2, 1855, p.505.

Anomala rufiventris, Arrow, Fauna Brit. Ind., Coleopt. Lamell., II, 1917, p.202, 236.

Anomala rufiventris, Paulian, Ann. Soc. ent. France, CXXVIII (1958) 1959, p.39, 41, f.82, 83, 84.

Material examined: 10.v.1996, 1 ex., GHNP, Sainj, alt. 2100m, coll. V.P. Uniyal.

Diagnosis: Length 16.0-22.0mm, breadth 10.0-11.0mm; body elongate, ovate; smooth and shining, very dark bronzy-green, sternum and legs greenish-black and ventral abdominal segments mahogany red, pygidium with few long and erect hairs. Clypeus short and minutely punctate.
Pronotum thinly and very minutely punctate, base gently trisinuate, with a marginal line interrupted in middle; scutellum scarcely finely punctate; elytra with inconspicuous lines of extremely minute punctures; mesosterum not produced; longer claw of fore and middle legs deeply cleft. Pygidium smooth and shining in middle, and finely rather rugosely punctate at sides.

Distribution: India (Himachal Pradesh, Uttar Pradesh, West Bengal, Manipur, Meghalaya, Sikkim) and Bhutan.

\section{Subfamily: Dynastinae Xylotrupes gideon (Linnaeus)}

Scarabaeus gideon Linnaeus Syst. Nat. 12th ed., I0(2), 1767, p.541. Scarabaeus gideon, Olivier, Ent. I (3), 1789, p.14, p.1,2,f.102. Scarabaeus gideon, Burmeister, Handb. Ent. V, 1847, p.266. Xylotrupes gideon ,Arrow, Fauna Brit. Ind. I, 1910, p.262. Xylotrupes gideon, Endrodi, Acta. Biol.II (1-3), 1951, p.243-252.

Material examined: 19.v.1996, 1 ex. (male), GHNP, Sainj, alt. 2120m, coll. V.P. Uniyal.

Diagnosis: Length 29.0-38.0mm, breadth 16.0-23.0mm; body oval, convex, broad; chestnut-red or dark-brown, sternum and hind coxae clothed with fine hairs. Head very strongly and coarsely punctate, armed with a laterally compressed horn projecting obliquely forward and upward, terminating in two diverging rami curving backwards and carinate behind. Pronotum in male very finely and sparsely punctate, drawn out into a cone-like horn directed obliquely forward, with apex gently bifid and carinate ventro-laterally. Female without any armature, pronotum very strongly sculptured, elytra finely and sparsely punctate.

Distribution: India (Himachal Pradesh, Andaman, Sikkim, Assam, Maharashtra, Kerala, West Bengal) and Sri Lanka to Indo-Malayan sub region. 
Oryctes nasicornis (Linnaeus)

Scarabaeus nasicornis Linnaeus, Syst. Nat. ed.X.i, 1758, p.346 . Scarabaeus nasicornis, Burm., Handb. Ent. V,1847,p.193. Scarabaeus nasicornis, Camerano, Bull. Soc. Ent. Ital. X, 1878, p.21. Oryctes nasicornis, Arrow, Fauna Brit. Ind. I. 1910, p.275.

Material examined: 10.v.96 (female), 2 ex., GHNP, Sainj, alt. 2100m; 27.v.96 (male), Sainj, alt. 2050m, coll. V.P. Uniyal.

Diagnosis: Length, $26.0 \mathrm{~mm}$, breadth $13.0 \mathrm{~mm}$; moderately elongate, oval; chestnut-red above and shining, head and margin of pronotum little darker, clothed with tawny hairs beneath. Clypeus tapering and blunt in front. Scutellum irregularly punctate with few punctures, smooth on outer margin; elytra finely and irregularly punctate, with a strongly impressed row of coalescing punctures adjoining suture, and slight traces of other double series; fore tibia tridentate. Propygidium covered with fine stridulatory files. In male, disc of pronotum in front excavated with its upper margin feebly-tridentate.

Distribution: India (Himachal Pradesh, Kashmir) Pakistan, South-East Asia and South-East Europe.

\section{Phyllognathus dionysius (Fabricius)}

Scarabaeus dionysius Fabricius, Ent. Syst.I, 1792, p.20.

Geotrupes dionysius, Syst. Eleuth. I, 1801, p.17.

Oryctes dionysius, Burmeister, Handb. Ent. V,1 847, p.188.

Oryctes dionysius, Arrow, Fauna Brit. Ind. Lamell. I, 1910, p.307.

Oryctes dionysius, Endrodi, Ent. Arb. Mus. Frey, 20, 1969, p.451.

Material examined: 28.iv.1996, 1 ex., GHNP, Sainj, alt. 1630m, coll. V.P. Uniyal.

Diagnosis: Length 16.0-23.0mm, breadth $9.5-13.0 \mathrm{~mm}$; body compact and globose; chestnut-red, shining above and clothed with tawny hairs beneath. Head densely and rather rugosely punctate. Pronotum strongly and finely punctate, rugosely in front; elytra strongly and moderately closely punctate with annular puncture, some arranged in longitudinal rows. In male, cephalic horn broad, strongly inclined backwards, triangular at extremity with apex acute; pronotum deeply excavated from front to almost hind margin, with sides slightly curved outwards and prominent anteriorly in middle.

Distribution: India (Himachal Pradesh, Uttar Pradesh, Haryana, Sikkim, West Bengal, Maharashtra, Tamil Nadu, Orissa and Karnataka) and Sri Lanka.

\section{Subfamily: Cetoniinae Protaetia neglecta (Hope)}

Cetonia neglecta Hope in Gray, Zool. Miscel 1.1831, p.24.

Cetonia neglecta, Burmeister, Handb. Ent. III, 1842, p.792.

Protaetia neglecta, Arrow, Fauna Brit. India, Lame II. I, 1910, p.138, 160.

Material examined: 14.v.1996, 1 ex., GHNP, Sainj, alt. 1810m., coll. V.P. Uniyal.

Diagnosis: Length $21.0 \mathrm{~mm}$, breadth $12.0 \mathrm{~mm}$; body rather convex opaque, bronzy with slight metallic luster, covered with brown-velvety bloom, with coppery-greenish and strongly punctate, lower surface with shining luster. Head coarsely punctuate and front margin minutely reflexed in middle. Pronotum strongly rugose on sides; scutellum long, with apex blunt, and impunctate; elytra very strongly and rugosely punctate except around scutellum; metasternum coarsely and rugosely punctate except in middle; sternal process short, broader than its length; front tibiae armed with three rather sharp teeths. Pygidium finely and closely granulate.

Distribution: India (Himachal Pradesh, Haryana, Uttar Pradesh, Punjab, Assam, Manipur) and Nepal.

\section{Discussion}

The scarabaeid fauna of the GHNP shows varied zoogeographical links with the fauna of other regions. Most of the representatives show their affinity with fauna of Palaearctic region and a few share the distribution of Australian and Ethiopian regions. In Himalayan range, north-south zonal stratification is prevalent and east-west zonal stratification is hardly visible. In this region, altitude acts as a limiting factor for the zonation of species and sometimes a change of altitude of even 100m limits the range of particular species, Melolontha, Hilyotrogus, Anomala rufiventris, Oryctes nasicornis, Phyllognathus dionysius are confined to high hill ranges and are never collected from the plains. Out of nine species collected from GHNP, five species i.e. Hilyotrogus holosericeus (Redtenbacher), Anomala rufiventris Redtenbacher, Oryctes nasicornis (Linnaeus), Phyllognathus dionysius (Fabricius) and Protaetia neglecta (Hope) are recorded for the first time from Kulu district.

\section{REFERENCES}

Arrow, G.J. (1910). The Fauna of British India Including Ceylon and Burma, Col, Lamellicornia I, (Cetoniinae and Dynastinae). Talyor \& Francis, London: V-XIV, 322pp +76 figs. +2 pls.

Arrow, G.J. (1917). The Fauna of British India Including Ceylon and Burma, Col. Lamellicornia II, (Rutelinae, Desmonychinae and Euchirinae). Taylor \& Francis, London: V-XIII, 387pp +77 figs. +5 pls

Arrow, G.J. (1932). A few new species of Melolonthine, Coleoptera. Annals and Magazine of Natural History 10(9): 189-197.

Arrow, G.J. (1944). Systematic notes on melolonthine beetles belonging to Holotrichia and related genera. Annals and Magazine of Natural History 11(11): 631-648.

Chandra, K. (1988). Taxonomic studies on pleurostict Scarabaeidae (Coleoptera) of north-west India. Y.E.S. Quarterely, U.S.A. 5(1): $20-27$.

Chandra, K. (2004). Insecta Coleoptera: Scarabaeidae-Fanna of Western Himalaya (Part 2). Himachal Pradesh. Zoological Survey of India, 141-155pp.

Uniyal, V.P. (1999). Yellow swallowtail butterfly Papilio machanon (Lepidoptera: Papilionidae) from Great Himalayan National Park, Himachal Pradesh. Annales of Forestry. 7(2):301-302.

Uniyal, V.P. \& N. Kumar (1997). Food preference of the yellow caster butterfly Pareba vesta (Nymphalidae: Lepidoptera) in the Great Himalayan National Park, Himachal Pradesh, Zoos' Print XII (5): 7-8.

Uniyal, V.P. \& P.K. Mathur (1998). Diversity of butterfly in Great Himalayan National Park, Western Himalaya, Indian Journal of Forestry 21(2): 150-155. Uniyal, V.P. \& P.K. Mathur (2000). Altitudinal distribution of tiger beetles (Cicindelidae: Coleoptera) in Great Himalayan National Park Conservation Area, Western Himalaya. Indian Forester 126(10): 1141-1143.

\section{ACKNOWLedgements}

The authors are thankful to the Director, Zoological Survey of India, Kolkata and Director, Wildlife Institute of India, Dehradun for necessary facilities to carry out this work and for their encouragement.

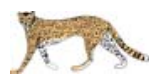

